\title{
Bioteknologi Berbasis Bioentrepreneurship: Persepsi Mahasiswa Biologi
}

\author{
Agus Muliadi ${ }^{1}$, Ali Imran ${ }^{2 *}$, Sabrun $^{3}$ \\ ${ }^{1}$ Pendidikan Biologi, FSTT, Universitas Pendidikan Mandalika \\ ${ }^{2}$ Pendidikan Olahraga, FIKKM, Universitas Pendidikan Mandalika \\ ${ }^{1}$ Pendidikan Matematika, FSTT, Universitas Pendidikan Mandalika \\ E-mail: aliimran@undikma.ac.id
}

\begin{abstract}
Abstrak
Studi ini bertujuan untuk mengeksplorasi persepsi mahasiswa pendidikan biologi terhadap pembelajaran bioteknologi berbasis bioentrepreneurship. Studi ini merupakan penelitian deskriptif eksploratif dimana responden adalah 56 mahasiswa pendidikan biologi di Universitas Pendidikan Mandalika. Instrumen yang digunakan berupa angket tertutup dengan skala Guttman dan yang telah divalidasi (validasi ahli). Data penelitian dianalisis secara deskriptif dan statistik inferensial dengan uji Kruskal Wallis. Hasil studi yaitu (1) persepsi mahasiswa pendidikan biologi di Universitas Pendidikan Mandalika terhadap pembelajaran bioteknologi berbasis bioentrepreneurship adalah sangat baik dengan rincian persentase pesepsi mahasiswa semester II sebesar $67,5 \%$, semester IV sebesar $82,5 \%$, semester VI sebesar 96,9\%, dan semester VIII sebesar 90\%; (2) hasil uji kruskal wallis dengan nilai signifikansi sebesar 0,002 lebih kecil dari nilai alpha pengujian alpha pengujian $(>0,05)$, sehingga dapat disimpulkan bahwa ada perbedaan signifikan persepsi mahasiswa pendidikan biologi terhadap pembelajaran bioteknologi berbasis bioentrepreneurship.
\end{abstract}

Kata kunci: bioteknologi, bioentrepreneurship, persepsi mahasiswa

\section{PENDAHULUAN}

Indonesia adalah salah satu negara dengan penduduk terbanyak di dunia yaitu tercatat pada tanggal 30 Juni 2020 total penduduk sebanyak 268.583.016 jiwa. Bangsa dengan penduduk yang banyak, pemerintah Indonesia kerap kali dihadapkan berbagai permasalah sosial seperti penuntasan kemiskinan, penyediaan lapangan pekerjaan, sarana dan prasarana pendidikan, pangan, sandang, dan masah lainnya. Merujuk pada data publikasi Badan Pusat Statistik (BPS) pada bulan Mei 2020 bahwa Tingkat Pengangguran Terbuka (TPT) di Indonesia sebesar 4,99\% pada Februari 2020 turun dibandingkan Februari 2019 sebesar 5,01. Tingkat Pengangguran Terbuka (TPT) lulusan perguruan tinggi yaitu Diploma I,II,III sebesar 6,76 dan Universitas sebesar 5,73 (BPS, 2020). Data ini menunjukkan bahwa lulusan perguruan tinggi belum siap sepenuhnya untuk mandiri dalam membangun pekerjaan (job creator), tetapi masih memiliki pola pikir pencari kerja (job seeker) (Muliadi, Mirawati \& Prayogi, 2021; Muliadi, Imran \& Sutarto, 2021; Subagio, Muliadi \& Sutarto, 2021; Muliadi, Asri \& Lestarini, 2020).

Perguruan tinggi memerlukan kebijakan pengembangan berbasis masyarakat luas (Broad Based Education) dan berorientasi pada kecakapan hidup (life skill) untuk menghasilkan lulusan yang cakap, kreatif, inovatif, kompetitif, dan mandiri (Wahyuni \& Hidayati, 2017; Muliadi \& Mirawati, 2020). Keterampilan wirausaha memiliki peranan penting bagi lulusan dalam menciptakan lapangan kerja dan membantu pertumbungan ekonomi masyarakat dan bangsa secara umum (Ejilibe, 2012; Quirk, 2003). Pembelajaran biologi yang memiliki konsep terapan dapat memberikan kesempatan kerja bagi yang mempelajarinya, sehingga biologi merupakan pembelajaran penting diajarkan di universitas di seluruh dunia (Ejilibe, 2012; Pascale, 2007). Perguruan tinggi di Indonesia, khususnya program sarjana pendidikan biologi merupakan salah satu jenis pendidikan formal yang diarahkan memiliki kemampuan mengembangkan kewirausahaan yang berkaitan dengan biologi (Direktorat Pembelajaran dan Kemahasiswaan, 2013). Oleh karena itu, program perkuliahan biologi diharapkan dapat memfasilitasi mahasiswa untuk mengembangkan kompetensi bidang kewirausahaan berbasis ilmu biologi (Natadiwijaya, et al., 2018).

Program studi pendidikan biologi pada Fakultas Sains, Teknik, dan Terapan (FSTT) Universitas Pendidikan Mandalika saat ini sudah mewajibkan matakuliah wirausaha 
dalam kurikulumnya agar dapat memfasilitasi pengembangan kecakapan hidup (life skill) bagi lulusannya. Pendidikan kewirausahaan masih sangat terbatas dengan kredit hanya 2 SKS, sedangkan proses pengembangan kecakapan hidup (life skill) mahasiswa harus komprehensif, sehingga memerlukan waktu dan pengalaman yang berulang, terstruktur, dan berjenjang. Oleh karena itu, diperlukan adanya pengintegrasian nilai-nilai kewirausahaan (entrepreneur) dalam setiap pembelajaran biologi yang bersifat terapan/aplikatif seperti bioteknologi dan mikrobiologi (Muliadi, 2019; Muliadi, 2020).

Pembelajaran biologi berbasis kewirausahaan dapat memberikan pengalaman dan keterampilan yang dibutuhkan mahasiswa untuk membangun usaha dengan memanfaatkan ilmu hayati (Ovie, 2011). Lebih lanjut dijelaskan oleh Ezeudu (2008) dan Omoifo (2008) bahwa pembelajaran biologi berbasis kewirausahaan dapat membekali individu dengan kemampuan mengenali peluang komersil, wawasan, pengetahuan, dan keterampilan untuk menindaklajutinya. Kewirausahaan dapat dikembangkan salah satunya melalui penciptaan produk-produk biologi pada pembelajaran bioteknologi (Collet \& Wyatt, 2005). Bioteknologi dalam arti luas merupakan teknik yang menggunakan organisme untuk membuat atau memodifikasi produk, guna meningkatkan pemanfaatan tumbuhan dan hewan atau untuk mengembangkan mikroorganisme untuk tujuan khusus (Acquaah, 2004). Oleh karena itu, penting untuk dapat mengembangkan perkuliahan yang memfasilitasi mahasiswa dapat menghubungkan konsep-konsep bioteknologi pada peluang wirausaha di Indonesia. Pengintegrasian muatan nilai-nilai kewirausahaan kedalam bidang ilmu hayati seperti bioteknologi dikenal dengan istilah bioentrepreneurship (Natadiwijaya, et al., 2018). Pendidikan bioentrepreneurship adalah suatu program pendidikan yang dirancang untuk mengajarkan pengetahuan, keterampilan dan sikap yang dibutuhkan bagi seorang wirausahawan yang tertarik kepada komersialisasi produk ilmu hayati (Langer, 2014).

Muliadi (2019) menegaskan bahwa pembelajaran biologi terapan seperti bioteknologi hendaknya dibelajarkan secara kontekstual dan aplikatif dengan 'memanfaatkan' mahluk hidup dan lingkungannya (sumber daya alam) secara bijak. Pembelajaran bioteknologi berbasis bioentrepreneurship diharapkan dapat memfasilitasi mahasiswa untuk memiliki pengetahuan dan kecakapan hidup (life skill), sehingga menjadi lulusan yang profesional, inovatif, produktif, kompetitif dan dapat menciptakan lapangan pekerjaan (job creator). Oleh sebab itu, diperlukan adanya studi untuk mengetahui persepsi mahasiswa pendidikan biologi tentang pembelajaran bioteknologi berbasis bioentrepreneurship.

\section{METODE}

Penelitian ini merupakan penelitian deskriptif eksploratif (Sugiyono, 2017; Arikunto, 2016; Singarimbun \& Sofyan, 2009). Penelitian ini bertujuan untuk mendeskripsikan persepsi mahasiswa tentang pembelajaran bioteknologi berbasis bioentrepreneurship. Responden adalah 56 mahasiswa pendidikan biologi di Fakultas Sains, Teknik, dan Terapan (FSTT) Universitas Pendidikan Mandalika. Intrumen penelitian ini adalah angket tertutup dengan pilihan jawaban menggunakan skala Guttman (Muliadi, 2020). Angket persepsi mahasiswa terhadap pembelajaran bioteknologi berbasis bioentrepreneurship dikembangkan mengacu pada indikator persepsi tentang pengetahuan kewirausahaan, pembelajaran bioteknologi, relevansi konsep bioteknologi, bioentrepreneurship. Indikator ini dikembangkan menjadi pertanyaan dalam angket dan divalidasi oleh para pakar (expert) dan dinyatakan valid.

Analisis data penelitian dilakukan secara deskriptif dan statistik inferensial. Analisis deskriptif digunakan untuk mendeskripsikan persepsi mahasiswa terhadap pembelajaran bioteknologi berbasis bioentrepreneurship. Rata-rata persepsi $(\bar{p})$ dikonversi dalam bentuk kategori berdasarkan 
tabel intepretasi berikut ini (Muliadi \& Mirawati, 2020).

Tabel 2. Interpretasi rata-rata skor persepsi mahasiswa

\begin{tabular}{cc}
\hline Persentase & Interpretasi \\
\hline $76-100 \%$ & Sangat Baik \\
$56-75 \%$ & Cukup Baik \\
$40-55 \%$ & Kurang Baik \\
$<40 \%$ & Tidak Baik \\
\hline
\end{tabular}

Statistik inferensial yang digunakan untuk mengetahui perbedaan persepsi mahasiswa pendidikan biologi tiap semester. Teknik analisis yang digunakan adalah uji Kruskal Wallis pada taraf signifikansi 5\%, uji ini digunakan karena varians data tidak homogen dan tidak terdisribusi normal. Rumusan hipotesis statistik yaitu $\mathrm{H}_{0}: \mu 1=\mu 2$ (tidak ada perbedaan signifikan persepsi mahasiswa pendidikan biologi antar semester terhadap pembelajaran bioteknologi berbasis bioentrepreneurship) dan $\mathrm{H}_{1}: \mu 1 \neq \mu 2$ (ada perbedaan signifikan persepsi mahasiswa pendidikan biologi antar semester terhadap pembelajaran bioteknologi berbasis bioentrepreneurship). Jika hasil analisis signifikan atau $p$-value uji korelasi lebih kecil dari 0,05 , maka $\mathrm{H}_{0}$ ditolak dan $\mathrm{H}_{1}$ terima atau sebaliknya.

\section{HASIL DAN PEMBAHASAN}

Pengukuran persepsi mahasiswa pendidikan biologi terhadap pembelajaran bioteknologi berbasis bioentrepreneurship diberikan kepada semester II sebanyak 10 orang, semester IV sebanyak 20 orang, semester VI sebanyak 16 orang, dan semester VIII sebanyak 10 orang. Deskripsi data hasil pengukuran persepsi mahasiswa pendidikan biologi terhadap pembelajaran bioteknologi berbasis bioentrepreneurship disajikan pada Tabel 2 berikut ini:

Tabel 2. Persepsi mahasiswa tentang bioteknologi berbasis bioentrepreneurship

\begin{tabular}{ccccc}
\hline Semester & $\mathbf{\Sigma}$ & $\boldsymbol{\Sigma}$ Skor Persentase & Kategori \\
\hline II & 10 & 27 & $67,5 \%$ & Cukup Baik \\
IV & 20 & 66 & $82,5 \%$ & Sangat Baik \\
VI & 16 & 62 & $96,9 \%$ & Sangat Baik \\
VIII & 10 & 36 & $90 \%$ & Sangat Baik \\
\hline
\end{tabular}

Berdasarkan data pada Tabel 2, diketahui bahwa persepsi mahasiswa pendidikan biologi terhadap pembelajaran bioteknologi berbasis bioentrepreneurship yaitu mahasiswa semester II memiliki persentase sebesar 67,5\% dengan kategori Cukup Baik; semester IV sebesar $82,5 \%$ dengan kategori Sangat Baik; semester VI sebesar 96,9\% dengan kategori Sangat Baik; semester VIII sebesar 90\% dengan kategori Sangat Baik. Berdasarkan deskripsi data tersebut, maka diketahui bahwa persepsi mahasiswa semester VI dan VIII adalah yang terbaik dengan persentase $\geq 90 \%$ dan kategori Sangat Baik.

Data persepsi mahasiswa pendidikan biologi terhadap pembelajaran bioteknologi berbasis entrepreneurship dianalisis menggunakan statistik parametrik, dengan syarat varians data homogen dan terdistribusi normal. Hasil uji homogenitas (Levenestest) dan normalitas (Kolmogorov-Smirnov's test) dijadikan pada Tabel 3 berikut ini.

Tabel 3. Hasil uji homogenitas dan normalitas

\begin{tabular}{ccccc}
\hline N & \multicolumn{2}{c}{$\begin{array}{c}\text { Homogenitas } \\
\text { Levenes } \\
\text { Statistic test } \\
\text { score }\end{array}$} & Sig. & \multicolumn{2}{c}{$\begin{array}{c}\text { Normalitas } \\
\text { Kolmogorov- } \\
\text { Smirnov's } \\
\text { test score }\end{array}$} & Sig. \\
\hline 56 & 5,797 & 0,02 & 1,366 & 0,48
\end{tabular}

Hasil uji homogenitas (Levenes test) dan normalitas (Kolmogorov-Smirnov's test) berturut-turut sebesar 5,797 dan 1,366, keduanya memiliki nilai signifikansi lebih kecil dari alpha pengujian $(>0,05)$, dan dapat dinyatakan varian data tidak homogen dan tidak terdistribusi normal. Selanjutnya, data perbedaan persepsi mahasiswa pendidikan biologi tiap semester dianalisis menggunakan statistik non parametrik yaitu uji Kruskal Wallis. Hasil uji Kruskal Wallis disajikan pada Tabel 4 berikut ini.

Tabel 4. Hasil uji Kruskal Wallis

\begin{tabular}{lccc}
\multicolumn{1}{c}{ Varians } & Che-Squares & df & Sig. \\
\hline Persepsi & 14,877 & 3 & 0,002 \\
Mahasiswa & & &
\end{tabular}

Hasil uji Kruskal Wallis menunjukkan bahwa nilai signifikansi sebesar 0,002 lebih kecil dari nilai alpha pengujian alpha pengujian $(>0,05)$, sehingga $\mathrm{H}_{1}$ diterima dan 
$\mathrm{H}_{0}$ ditolak yang artinya bahwa ada perbedaan yang signifikan persepsi mahasiswa pendidikan biologi terhadap pembelajaran bioteknologi berbasis bioentrepreneurship. Sedangkan hasil uji lanjut menggunakan uji Tukey HSD disajikan nenunjukkan bahwa persepsi semester II berbeda signifikan dengan semester VI dan VIII dengan nilai signifikansi berturut 0,001 dan 0,025 , tetapi tidak berbeda signifikan dengan semester IV dengan nilai signifikansi 0,121 . Sedangkan persepsi mahasiswa semester IV tidak memiliki perbedaan signifikan dengan semester VI dan VIII nilai signifikansi sebesar 0,072 dan 0,673.

Elaborasi hasil penelitian ini menunjukkan bahwa mahasiswa semester II memiliki persepsi yang berbeda perbedaan dengan mahasiswa semester IV,VI,VIII terhadap pembelajaran bioteknologi berbasis bioentrepreneurship. Mahasiswa semester IV, VI, VIII memiliki persepsi sangat baik, sedangkan semester II cukup baik. Hal ini disebabkan banyak faktor, salah satunya adalah tingkat pengetahuan mahasiswa semester II tentang bioteknologi dan kewirausahaan yang masih kurang karena belum menempuh matakuliah bioteknologi dan pendidikan kewirausahaan. Pengalaman mahasiswa mengikuti perkuliahan bioteknologi dan pendidikan kewirausahaan tentunya akan mempengaruhi pengetahuan akan kewirausahaan dan bioteknologi dan selanjutnya akan mempengaruhi persepsi dan sikap mahasiswa terhadap integrasi nilai-nilai kewirausahaan (entrepreneurship) dalam pembelajaran bioteknologi. Hal ini dibuktikan dengan adanya persepsi yang sangat baik dari mahasiswa semester IV,VI,VIII yang telah mengikuti perkuliahan bioteknologi dan pendidikan kewirausahaan.

Persepsi positif mahasiswa pendidikan biologi terhadap pembelajaran bioteknologi berbasis bioentreprenurship menjelaskan bahwa nilai-nilai kewirausahaan sangat relevan untuk diitegrasikan dalam materi bioteknologi. Hal ini sesuai dengan pendapat Natadiwijaya, et al. (2018) bahwa kewirausahaan dapat dikembangkan salah satunya melalui penciptaan produk-produk biologi pada mata kuliah yang bersifat aplikatif seperti bioteknologi. Menurut Acquaah (2004) bioteknologi dalam arti luas adalah beberapa teknik yang menggunakan organisme hidup atau prosesnya untuk membuat atau memodifikasi produk, guna meningkatkan pemanfaatan tumbuhan dan hewan atau untuk mengembangkan mikroorganisme untuk tujuan khusus. Oleh karena itu, integrasi muatan kewirausahaan dalam konsep-konsep bioteknologi (bioentrepreneurship) dapat membangun peluang berwirausaha.

Langer (2014) menegaskan bahwa pendidikan bioentrepreneurship merupakan suatu program pendidikan yang dirancang untuk mengajarkan pengetahuan, keterampilan, dan sikap yang dibutuhkan bagi seorang wirausahawan yang tertarik kepada komersialisasi produk ilmu hayati. Hasil penelitian tentang bioentrepreneurship menunjukkan bahwa bioentrepreneurship dapat meningkatkan keterampilan proses siswa (Mutia \& Tumisem, 2015), dapat meningkatkan sikap wirausaha peserta didik pada pembelajaran pengetahuan lingkungan (Mulyaningrum, 2014). Hasil penelitian lainnya menunjukkan bahwa perkuliahan bioteknologi bermuatan bioentrepreneurship koheren dengan sikap wirausaha mahasiswa yang baik dan lebih menyadari relevansi antara bioteknologi dengan kewirausahaan, mampu membuat produk dan mensosialisasikannya, serta dapat meningkatkan minat terhadap bioteknologi (Natadiwijaya, et al., 2018).

Persepsi mahasiswa yang positif tentang pembelajaran bioteknologi berbasis entreprenuership mengambarkan tingginya harapan mahasiswa terhadap kompetensi wirausaha untuk membangun masa depan. Pembelajaran kewirausaha dapat mengembangkan keterampilan wirausaha mahasiswa dan lulusan dalam menciptakan lapangan kerja dan membantu pertumbungan ekonomi masyarakat dan bangsa secara umum (Ejilibe, 2012; Quirk, 2003). Pembelajaran biologi yang memiliki konsep terapan dapat memberikan kesempatan kerja bagi yang mempelajarinya (Ejilibe, 2012; Pascale, 
2007). Pembelajaran biologi berbasis entrepreneurship dapat memberikan pengalaman dan keterampilan yang dibutuhkan mahasiswa untuk membangun usaha dengan memanfaatkan ilmu hayati (Ovie, 2011). Lebih lanjut dijelaskan oleh Ezeudu (2008) dan Omoifo (2008) bahwa pembelajaran biologi berbasis entrepreneurship dapat membekali individu dengan kemampuan mengenali peluang komersil, wawasan, pengetahuan, dan keterampilan untuk menindaklajutinya.

Fakta penelitian ini yang didukung penelitian sebelumnya memastikan bahwa konsep pembelajaran bioteknologi berbasis bioentrepreneurship sangat relevan untuk diterapkan di perguruan tinggi. Hal ini sesuai dengan hakekat pembelajaran biologi yang mengutamakan discovery, inquiry, constructivism, contextual dan science, technology, and society (Ulwiyah, 2010). Pembelajaran bioentrepreneurship merupakan pembelajaran kontekstual yang dapat memfasilitasi pengalaman belajar bagai mahasiswa untuk mengamati, mengidentifikasi, mengkaji, menganalisis dan memanfaatkan biodiversitas dan bioteknologi untuk menciptakan produk yang mengandung nilai ekonomi (Muliadi, 2020). Priyato (2009) menyatakan bahwa pengintegrasian nilai-nilai kewirausahaan dalam pembelajaran bioteknologi hendaknya memperhatikan potensi lokal daerah masing-masing. Pembelajaran bioteknologi berbasis bioentrepreneurship dapat memberikan pengalaman belajar kepada mahasiswa pendidikan biologi untuk menjadi academic entrepreneurship yang memiliki nilai-nilai seperti mandiri, kreatif, berani mengambil resiko, berorientasi pada tindakan, kepemimpinan, kerja keras, jujur, disiplin, inovatif, tanggung jawab, kerjasama, pantang menyerah, komitmen, realistis, rasa ingin tahu, komunikatif, dan motivasi kuat untuk sukses (Rosmiadi, Janias \& Munawar, 2015; Kristianti, Bintari \& Ridlo, 2012; Ulwiyah, 2010).

\section{KESIMPULAN}

Hasil studi dapat disimpulkan bahwa (1) persepsi mahasiswa pendidikan biologi di Universitas Pendidikan Mandalika terhadap pembelajaran bioteknologi berbasis bioentrepreneurship adalah sangat baik dengan persentase semester II sebesar $67,5 \%$, semester IV sebesar 82,5\%, semester VI sebesar 96,9\%, dan semester VIII sebesar 90\%; (2) ada perbedaan signifikan persepsi mahasiswa pendidikan biologi terhadap pembelajaran bioteknologi berbasis bioentrepreneurship dengan nilai signifikansi uji kruskal wallis sebesar 0,002 lebih kecil dari nilai alpha pengujian alpha pengujian $(>0,05)$.

\section{DAFTAR PUSTAKA}

Acquaah, G. (2004). Understanding Biotechnology: An Integrated and Cyber-Based Approach. New Jersey: Prentice Hall

Arikunto. (2016). Prosedur Penelitian (Suatu Pendekatan Praktik). Jakarta: Rineka Cipta.

Badan Pusat Statistik. (2020). Keadaan Ketenagakerjaan Indonesia Februari 2020. Jakarta: Berita Resmi Statistik.

Collet, C \& Wyatt, D .2005."Bioneering”teaching biotechnology entrepreneurship at the undergraduate level. Education + Training, $47 \quad$ (6), 408-421. https://doi.org/10.1108/00400910510 617033

Direktorat Pembelajaran dan Kemahasiswaan (BELMAWA). (2013). Dokumen deskripsi umum dan learning outcome 12 prodi LPTK. [Online]. Tersedia:

http://lpm.iainbanten.ac.id/pocontent/poupload/LAMPIRAN3\%20 Deskripsi\%20 dan\%20Learning\%20Outcome\%201 2\%20PRODI\%20LPTK.pdf

Ejilibe, O.C. (2012). Entrepreneurship in Biology Education as a Means for Employment. Knowledge Review, 26 (3), 96-100. 
Kristianti, E.A., Bintari, S.H., Ridlo, S. (2012). Pengembangan Perangkat Pembelajaran Bioentrepreneurship Pembuatan Makanan dari Limbah Cair Pengolahan Kedelai. Journal of Innovative Science Education. 1 (1), 112-118.

Langer, L.J. (2014). Building a curriculum for bioentrepreneurs. [Online]. Tersedia: http://www.nature.com/bioent/2014/ 140801/full/bioe.2014.9.html

Muliadi, A. \& Mirawati, B. (2020). The Impact of Personal Attitude and Subjective Norm on Entrepreneurial Interest of Biological Education Students. E-Saintika: Jurnal Penelitian dan Pengkajian Ilmu Pendidikan, 4

https://doi.org/10.36312/esaintika.v4i3.307

Muliadi, A. (2019). Pembelajaran Biologi Berbasis Entrpreneurship. Proceeding National Conference: Education, Social Science, and Humaniora, 1 (1), 269-275.

Muliadi, A. (2020). Microbiology Learning Based On Bioentrepreneurship: Prospective Teacher's Perception. Jurnal Ilmu Sosial dan Pendidikan, 4 (4), 352-357. http://dx.doi.org/10.36312/jisip.v4i4. 1527

Muliadi, A. (2020). Perbedaan Gender dalam Sikap Entrepreneur Mahasiswa Pendidikan Biologi. Jurnal Ilmiah Mandala Education, 6 (2), 329-334. http://dx.doi.org/10.36312/jime.v6i2. 1439

Muliadi, A. (2020). Sikap Entrepreneur Mahasiswa Pendidikan Biologi. Jurnal Ilmu Sosial dan Pendidikan, 4 (3), 286-291. http://dx.doi.org/10.36312/jisip.v4i3. 1208

Muliadi, A., Asri, I.H. \& Lestarini, Y. (2020). Efek Pengetahuan dan Lingkungan Keluarga terhadap Sikap Entrepreneur Mahasiswa. Educatio: Jurnal Ilmu Kependidikan, 15 (2). https://doi.org/10.29408/edc.v15i2.2 $\underline{836}$

Muliadi, A., Imran, A. \& Sutarto. (2021). Motivasi Belajar Kewirausahaan Ditinjau Dari Hasil Belajar: Mediasi Gender?. JPIn: Jurnal Pendidik Indonesia, 4 (1). 48-59. https://doi.org/10.47165/jpin.v4i1.13 $\underline{0}$

Muliadi, A., Mirawati, B. \& Prayogi, S. (2021). The Effect Entrepreneurship Education and Subjective Norm on Biology Students' Self-Efficacy in Entrepreneurial. Prisma Sains: Jurnal Pengkajian Ilmu dan Pembelajaran Matematika dan IPA IKIP Mataram, 9 (1). 127-135. https://doi.org/10.33394/jps.v9i1.398 $\underline{1}$

Mulyaningrum, E. R. (2014). Efektifitas Pengembangan Perangkat Pembelajaran Bervisi "Rest" (Religion, Environment, Science, and Technology) dan Berpendekatan Bioentrepreneurship terhadap Prestasi Belajar Mahasiswa Biologi. Bioma: Jurnal Ilmiah Biologi, 3 (2), 50-63.

https://doi.org/10.26877/bioma.v3i2, \%20Oktober.641

Mutia, Iin \& Tumisem. (2015). Pembelajaran berbasis Bioentrepreneurship untuk meningkatkan keterampilan proses sains siswa kelas $X$ SMA Muhammadiyah 1 Purwokerto. Prosiding Semnas Sains \& Entrepreneurship, II (1), 34-39. http://repository.ump.ac.id/id/eprint/ $\underline{496}$

Natadiwijaya, I.F., Rahmat, A., Redjeki, S. \& Anggraeni, S. (2018). Sikap Wirausaha Mahasiswa Pada Perkuliahan Bioteknologi Bermuatan Bioentrepreneurship. MANGIFERA EDU: Jurnal Biologi and Pendidikan Biologi, 3 (1), 40-51. https://doi.org/10.31943/mangiferaed u.v3i1.11

Omoifo, C.N, (2008). Curriculum and Gender Equity In Entrepreneurship 
Education. Science is Fun. A publication of STAN Edo State branch 5th, edition 17-20.

Ovie, R.A. (2011). The relevance of STMEducation in the development of skills and women Empowerment. Academic Scholarship Journal. 3 (1), 179-183

Pascale, H. (2007). The importance of Science In Modern Society. New Jersey Prentise Hall. Upper Saddle River. 22.

Priyanto, S. (2009). Mengembangkan Pendidikan Kewirausahaan di Masyarakat. Jurnal PNFI, 1 (1), 57 82.

Quirk, R. (2003). Longman dictionary of Contemporary English. England pearson Education limited.

Rosmiati, Junias, D.T.S., Munawar. (2015). Sikap, Motivasi, dan Minat Berwirausaha Mahasiswa. Jurnal Manajemen dan Kewirausahaan, 17 (1), 21-30. https://doi.org/10.9744/jmk.17.1.21$\underline{30}$

Singarimbun, M. \& Efendi, S. (2006). Metode Penelitian Survai (Edisi Revisi). Jakarta Barat: Pustaka LP3ES Indonesia.

Subagio, Muliadi, A. \& Sutarto. (2021). Minat Berwirausaha Mahasiswa Calon Guru : Mediasi Gender? JPIn: Jurnal Pendidik Indonesia, 4 (1). 107-115.

https://doi.org/10.47165/jpin.v4i1.14 $\underline{1}$

Sugiyono. (2017). Metode Penelitian Kualitatif, Kuantitatif, dan $R \& D$. Bandung: Alfabeta.

Ulwiyah, N. (2010). Integrasi Nilai-nilai Entrepreneurship Dalam Proses Pembelajaran di Kelas Guna Menciptakan Academic Entrepreneur Berkarakter. Makalah pada Program Studi PGMI, Fakultas Agama Islam, Unipdu Jombang (Tidak diterbitkan) 